\title{
Consumer Behavior in the Information Economy: Generation Z
}

\author{
Ekaterina Anatolevna Grigoreva ${ }^{1}$, Liliya Fuatovna Garifova ${ }^{1}$ \& Elvira Anasovna Polovkina ${ }^{1}$ \\ ${ }^{1}$ Associate Professor of Economic theory and econometrics department, Institute of Management, Economics and \\ Finance, Federal State Autonomous Educational Institution of Higher Education "Kazan (Volga region) Federal \\ University, Kazan, Russia \\ Correspondence: Ekaterina Anatolevna Grigoreva, Institute of Management, Economics and Finance, Kazan (Volga \\ region) Federal University, Kazan, Russia. E-mail: ekaterina_kazan@mail.ru \\ Received: October 9, 2020 \\ Accepted: December 1, 2020 \\ Online Published: January 14, 2021 \\ doi:10.5430/ijfr.v12n2p164 \\ URL: https://doi.org/10.5430/ijfr.v12n2p164
}

\begin{abstract}
The article examines the features of consumer behavior of Generation $\mathrm{Z}$, the largest consumer group in the world today. The authors highlight the ability and willingness to purchase goods and services online as the main trends in changing consumer behavior, while the main means of getting information, choosing a product (service), and paying for a purchase today are smartphones and tablets actively used by representatives of Generation Z. Generation Z has been determined to be digital consumers boldly shopping online. They stay online most of their time (working online, studying online, social media from 3 to 6 hours a day, watching movies and entertainment content online, etc.) and before purchasing anything, Generation $\mathrm{Z}$ expects to access to and evaluate information, reads reviews, and conducts its research. Generation Z looks forward to co-creation with brands, participation in teams, and collaboration with managers; it expects innovation from their employers, leaders, and brands. Due to this digital literate consumption, it makes highly informed, more pragmatic, and analytical decisions than representatives of previous generations. The article also shows that social networks are becoming the main channel for delivering advertising information to a young audience with a focus on visual content (video, infographics) and the shortest formats possible: Generation $\mathrm{Z}$ consumes information fragmentarily, as they use several devices simultaneously.
\end{abstract}

Keywords: generation Z, consumer behavior, social media, brands, bloggers

\section{Introduction}

As of the beginning of 2020, more than 4.5 billion people used the Internet, and the audience of social networks exceeded 3.8 billion users; the number of social networks audience in Russia amounted to 70 million users, that is, $48 \%$ of the total population of the country (Yeh et al., 2020). Social media is "a group of Internet applications that are based on the ideological and technological foundations of Web 2.0 and that provide the creation and exchange of user-generated content" (Kaplan \& Haenlein, 2010). Compared to traditional media such as television and newspapers, social media has greater reach, interactivity, usability, and ubiquity (Baccarella et al., 2018).

Internet users, both individuals, and organizations can not only consume and share existing information but also create and publish new text and video content. Social media, being a powerful tool, has become an integral part of everyday life. A recent Global Web Index survey found that $98 \%$ of online users spend 2.25 hours on social media, which is one-third of their daily online hours, and respondents aged 16-24 reported the most intense daily use of social media networks (Bayindir \& Kavanagh, 2018).

Perhaps the best examples to illustrate the influence of the media are the popular revolutions in the Middle East and Africa and the Islamic Awakening movement. Many journalists and experts call these revolutions Facebook and Twitter. In his weekly column in the New York Times, Thomas Friedman writes: "Facebook can launch a revolutionary wave, but it cannot be routed once it reaches the shore." He believes that new social networks and media have emerged as an accelerator to the wave that has been created in the Middle East and Africa for a variety of reasons. With the onset of the first sparks of the revolution in Tunisia, the role of the media, especially local satellites, in accompanying them was quite evident. Many of these countries' domestic satellite channels portrayed protests and changes in people's lives during the revolution and then the establishment of stability and security. The role of these networks became more prominent when political leaders and revolutionary leaders sought to explain their plans and positions and issue important statements, and these networks became the main source of news and developments and 
awareness of approaches and public opinion.

The ability to independently generate and publish content is a unique feature of social media. Regular users can create and share intriguing and engaging texts, photos, selfies, and videos that can attract followers. Once users such as bloggers, Instagrammers, or YouTubers get lots of followers on their respective platforms, they become "digital celebrities."

According to Liu et al. (2017), digital celebrities are easily accessible; they communicate frequently and directly with their followers. This high interactivity creates a strong intimacy and significant social impact on their followers (Jin \& Phua, 2014). This power allows them to play the role of opinion leaders who are able to shape the attitudes and behavior of their followers (Djafarova \& Rushworth, 2017). Today, Internet celebrities have successfully transformed their content creation and sharing into business opportunities by becoming virtual entrepreneurs. Recent studies have used the terms autopreneurship (Ashman et al., 2018), casual entrepreneurship, and user entrepreneurship (Haefliger et al., 2010).

Being on social media does not impose a lot of costs on the user and also does not require high expertise and literacy because most social media supports different languages, also due to the similarity of format and how to work in each type of social media and simple Being words and terms, the user can easily work in different media, even if they are in another language. As a result, the number of users and users of social media will increase day by day (Dimock, 2019).

In addition to ease of use, the possibility of personalization and freedom of expression that exists on social media increases the desire of people to write and send whatever they want. In social media, the line between the audience and the media is very blurred. Managers of these media rarely block users from posting because social media follows the rules of a free society. The possibility of joining various associations and interacting with people who have gathered around a specific topic or topics are also among the factors that draw people to social media.

Social media, on the other hand, expands its reach to links to sites and resources, which can also increase users' desire to join. For example, consider a site that sells the PDF file of the book you are looking for. But if you $\log$ in to the site with your Facebook account, you can download it for free.

Among the features mentioned, as well as other features of social media, personalization and having a kind of personal media, can be considered the most prominent factor in people's tendency to social media. People who are not seen in the community or deal with a limited audience have the opportunity on social media to share their words, ideas, and opinions on any topic in any way they like without imposing any restrictions on a large audience.

Presence on social media does not impose much cost on the user and also the specialization and social media in the last few years have made fundamental changes in the lifestyle of the citizens of the global village, although these changes in terms of geographical areas, cultures, and economic conditions of different communities (Smith \& Cawthon, 2017). They are weak, but they are not undeniable, just as they are not inevitable. To better understand the effects of social media and to be present as part of your lifestyle, it is best to refer to the statistics (Curtis et al., 2019):

* More than 294 billion emails are sent every day.

* More than 2 million blog posts are written every day.

* If Facebook were a country, it would be the third-largest country in the world today.

* Two new users enter LinkedIn every second.

* More than two billion likes are posted on Facebook every day.

* More than 340 million tweets are posted on Twitter every day.

* It costs more than $\$ 270,000$ per minute online.

* More than one and a half billion online users have said that they follow events through social brands! This is $20 \%$ of the world's population.

* In total, users spend more than 20,000 years on Facebook every day.

*Exchanges through social commerce will reach more than $\$ 30$ billion over the next five years.

Following the expansion of global connections, the role of generational transition became more important than the role of socioeconomic differences, and its effect on the regulation of behaviors became stronger (White, 2017; Persada et al., 2019). Young people had a greater impact on the types and varieties of other sections of society (at 
different ages) and incomes, and even changed the pattern of consumption and people's relationship with brands. Generation Z or Internet generation is the name of a group of people Who were born between 1990 and 2000 (Turner, 2015). The $Z$ generation, or the Internet generation, was literally born with a smartphone in hand; Known for their laziness and smartphone addiction, this generation is changing the business world in general. A generation that loves creativity and innovation is highly risk-averse and has indescribable skills in online searches and research (Ahmad et al., 2019; Alzeaideen, 2019).

In the current study, it was tried to examine the features of consumer behavior of Generation Z, the largest consumer group in the world today. The authors highlight the ability and willingness to purchase goods and services online as the main trends in changing consumer behavior, while the main means of getting information, choosing a product (service), and paying for a purchase today are smartphones and tablets actively used by representatives of Generation $\mathrm{Z}$.

\section{Method}

The main consumers in social networks are Generation Z. They perceive social networks as a source of news, entertainment, communication, and shopping. Generation $\mathrm{Z}$ in this article is those born between 1996-2012 and starting to represent the largest consumer group in the world. According to the American Bloomberg, which analyzed the UN data, by 2019, generation $\mathrm{Z}$ was supposed to surpass the number of "millennials" and reach $32 \%$ of the total population of the Earth (7.7 billion people) (Seemiller \& Grace, 2018). "Generation Z not only strives for more personalized products but is willing to pay a premium for products that emphasize their individuality," a McKinsey and Company's study states (Francis \& Hoefel, 2018). They haven't seen a world without the Internet, so they know how to use it better than anyone else. Such digital intelligent consumption helps them make highly informed decisions According to McKinsey, "they are more pragmatic and analytical in their decisions than previous generations" (Francis \& Hoefel, 2018). Before purchasing anything, Generation Z expects to access and evaluate information, reads reviews, and conducts its research. Generation Z looks forward to co-creation with brands, participation in teams, and collaboration with managers; it expects innovation from their employers, leaders, and brands (Hernandez-de-Menendez et al., 2020).

Here's a simple and straightforward example of a Starbucks brand and consumer interaction: you get their white thermo cup of coffee, paint it and send them a photo. They post you (the best of the best) on their social media page, advertising for and encouraging others to follow you. Nike is another example. It wanted to create a campaign that would be on everyone's lips and trigger real action with far-reaching consequences. To do this, they used TikTok as the fastest growing social network today. They identified three Milan TikTokers with a total of 11 million followers. The subscribers were all between the ages of 16 and 20 and known for posting the kind of well-liked dance challenges. The campaign yielded Nike $100 \mathrm{~m}+$ views and $540 \mathrm{k}+$ likes for three challenges, with $20 \mathrm{M}+$ \#basketbeat views in just 36 hours. In response, more than 46 thousand user subroutines have been published. Over 300 posts have been written about the campaign, reaching a readership of over 600 million. This includes our athletes appearing on the cover of Corriere Della Sera, one of the most conservative newspapers in Milan. Sky Sports - along with numerous other news outlets - broadcast the highlights of this campaign. Milan has become the fastest growing city in NIKE'S EMEA region as more and more young women see Nulla Puo Fermarci as a path to sports.

This is just one of the examples of brand-blogger interaction; such interaction pushes users to strive to become bloggers, to make money from collaboration. Generation $\mathrm{Z}$ has instant access to different sources of information and the ability to quickly spread their opinion, and this is both a plus and a minus for brands.

Below is a good example of how social media is changing with the interests of Generation Z.

Instagram is transforming from a social network for communicating with friends into a social network with huge opportunities for sales and brand promotion (see Figure 1). 


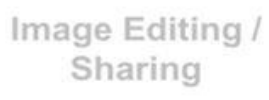

2011

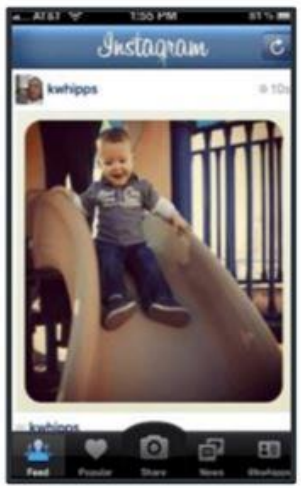

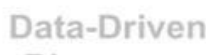

Discovery

2015

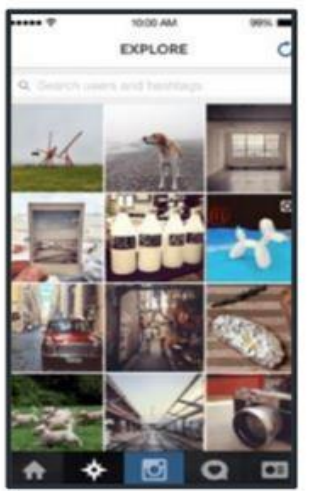

Image + Video

Stories

2016

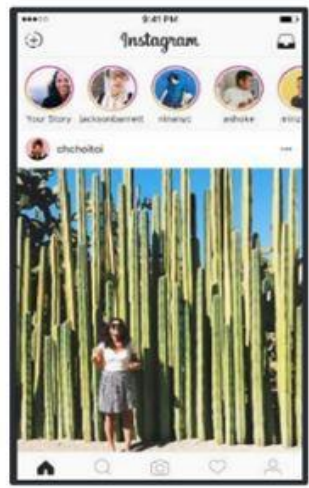

Commerce

2019

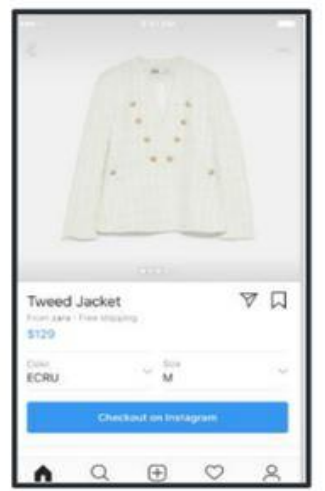

Figure 1. Instagram image sharing enhancement evolution (www.bondcap.com)

In 2011, the first profiles appeared on this social network; in 2015, advertising on Instagram became available all over the world; in 2016, it became possible to create a business profile; in June 2018, Instagram announced the number of users of this social network exceeded 1 billion; in 2019 there was a huge number of brands offering their products. The average age of Instagram users is 18-34 years [15]. Instagram is misconstrued as a "network for blondes." Statistical data refutes this thesis. Instagram has everything, with approximately the same ratio of men and women.

Figure 2 is the Pinterest network, a socially-functional visual bookmarking service that makes it easy to save pictures or videos from the Web to virtual boards. Pinterest has successfully intertwined the functions of a bookmark, a recommendation service, a message board, a wish list, plus all this is generously sprinkled with a social component.

\section{Pinterest Image Sharing Enhancement Evolution}

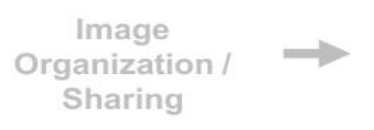

2011

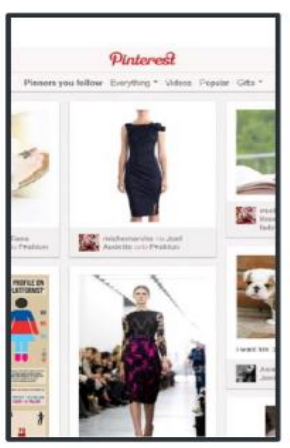

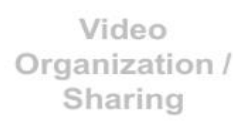

2012

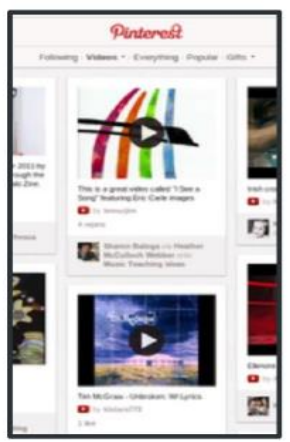

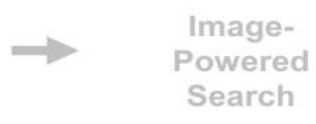

2015

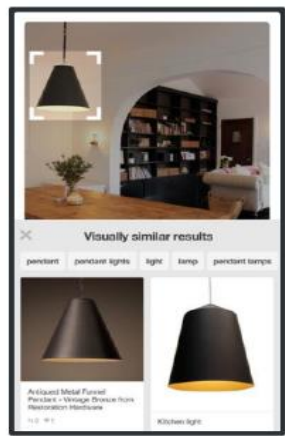

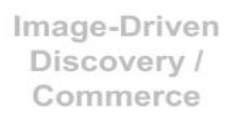

2019

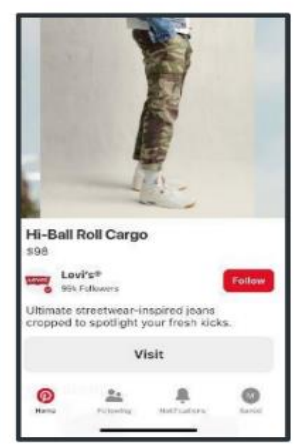

Figure 2. Pinterest image sharing enhancement evolution (www.bondcap.com) 
A link is often attached to a picture posted on one of the thematic boards to go to the company's website and learn more about the thing depicted. Thanks to these links, Pinterest generated more traffic to sites in February 2012 than Twitter, Google+, LinkedIn, and YouTube combined! As you can see, Pinterest also did the brand a favor, making the visual more suitable for advertising.

\section{Results}

We conducted a social survey to find out what "social" really means in today's social media landscape, whether Internet users are still enthusiastic about the social element of networking, or "social" has started to mean different things to users as maturation and development of the concept? Most of the respondents are Generation Z, as they are now the main consumers in social networks. Social media has undoubtedly become a "sensory extension" of consumers: we see, learn, buy, recommend, and demonstrate ourselves and our interests on social media.

Table 1. Social survey (compiled by the authors)

\begin{tabular}{|c|c|c|}
\hline Questions & Response options & $\begin{array}{l}\text { Number of } \\
\text { answers }\end{array}$ \\
\hline \multirow[t]{2}{*}{ Your gender } & Female & 2160 \\
\hline & Male & 630 \\
\hline \multirow[t]{5}{*}{ Your age } & $15-20$ & 1600 \\
\hline & $20-30$ & 860 \\
\hline & $30-40$ & 140 \\
\hline & $40-50$ & 110 \\
\hline & 50 and above & 100 \\
\hline \multirow[t]{6}{*}{ Your monthly income } & $\begin{array}{l}\text { No income (I live with parents / husband / } \\
\text { wife / relatives), temporary not working / } \\
\text { student }\end{array}$ & 1760 \\
\hline & Up to 20000 rub. & 480 \\
\hline & $20000-40000$ rub. & 210 \\
\hline & $40000-60000$ rub. & 150 \\
\hline & $60000-80000$ rub. & 100 \\
\hline & 80000 and above & 110 \\
\hline \multirow[t]{2}{*}{ Do you own a smartphone? } & Yes & 2750 \\
\hline & No & 60 \\
\hline \multirow[t]{6}{*}{ Do you use social media? } & Facebook / Instagram & 340 \\
\hline & Snapchat / TikTok & 0 \\
\hline & Vkontakte / Odnoklassniki & 170 \\
\hline & Pinterest, twitter or other & 0 \\
\hline & Several of the above & 2160 \\
\hline & Do not use any of the above & 140 \\
\hline \multirow{3}{*}{$\begin{array}{l}\text { Do you use any second digital device (iPad, laptop, } \\
\text { smartphone) while watching television? }\end{array}$} & Yes & 2030 \\
\hline & No & 770 \\
\hline & I do not watch television & 0 \\
\hline \multirow[t]{4}{*}{ How much time a day do you spend on social media? } & Up to 1 hour & 290 \\
\hline & $2-3$ & 630 \\
\hline & $3-5$ & 880 \\
\hline & 6 and longer & 990 \\
\hline \multirow[t]{3}{*}{ What is the main reason why you use social media? } & To keep in touch with family, friends & 1360 \\
\hline & To watch entertaining content & 660 \\
\hline & To watch educational content (sports, & 330 \\
\hline
\end{tabular}




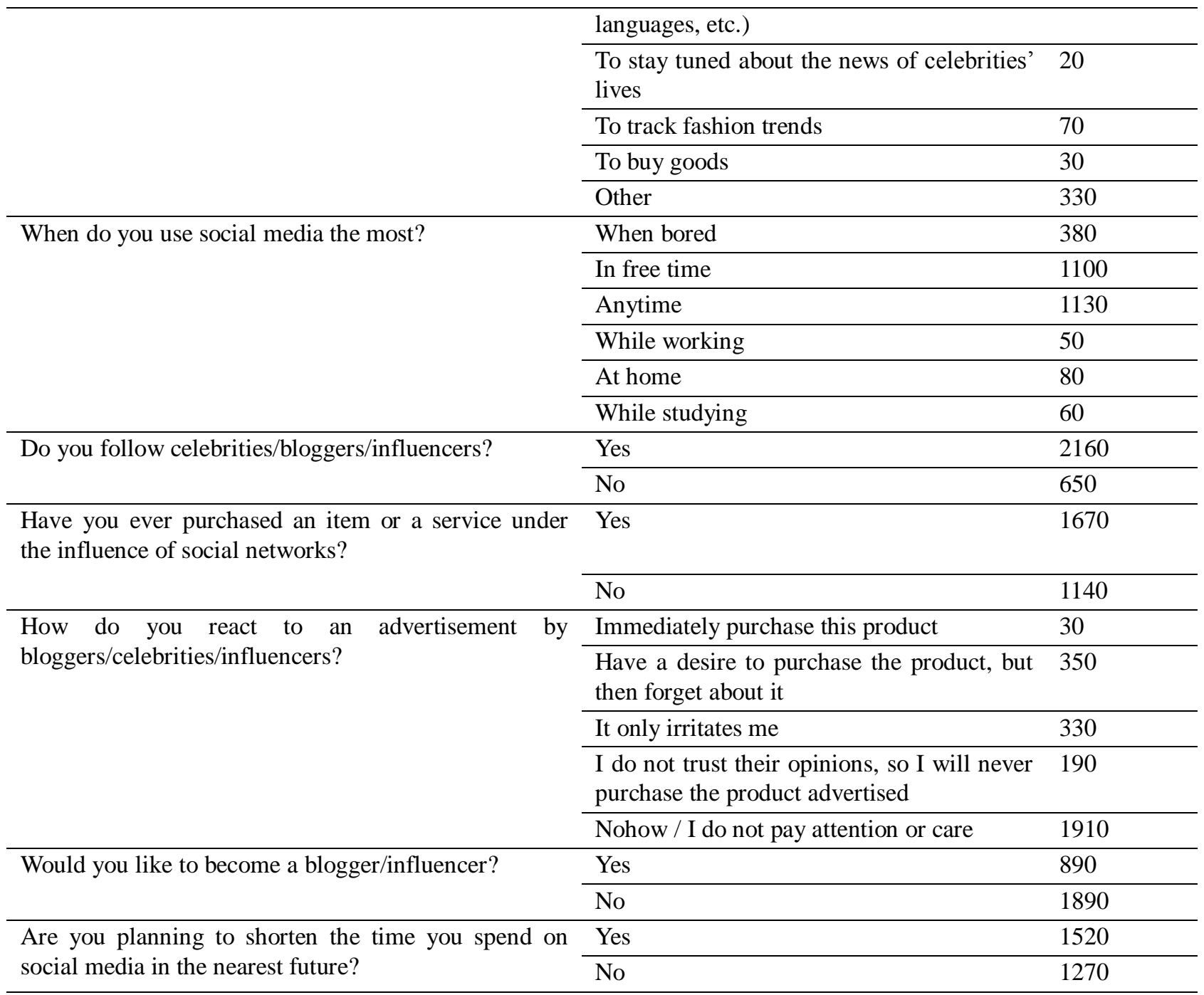

In our study, we also wanted to find out the role of social media in the daily life of the respondents, as well as the dependence of Generation $\mathrm{Z}$ on social networks (Table 1). In total, we interviewed 2,810 people; we tried to interview as many people from Generation $\mathrm{Z}$ as possible.

Among the respondents, $77 \%$ are women, 57\% are students aged 15 to 20 living on their parents. The survey has shown that $98 \%$ of respondents have smartphones, and almost $77 \%$ of them use several social networks. $48 \%$ still use social media to stay connected with friends and family but a very close rival is fun and entertaining content that gets people to turn to social media (23\%). 35\% of respondents spend 6 or more hours a day on social networks, $31 \%$ from 3 to 5 hours. More than $72 \%$ of respondents use a smartphone while watching TV to visit social networks. $77 \%$ of respondents follow celebrities / bloggers / influencers, 59\% purchased a product or service under the influence of social networks (advertising, native advertising), however, 68\% indicate that advertising from bloggers and celebrities does not work on them, while $32 \%$ would like to become influencers / bloggers.

The desire to become a blogger, in our opinion, makes the respondents stay on social networks longer to look for methods to promote themselves and their blog. Interestingly, 54\% plan to reduce their social media time in the future.

We can conclude that social networks have become an excellent platform for selling goods and services. People spend a lot of time on social networks, most of them are friendly to brands, bloggers, influencers, so the probability of making a purchase is high.

\section{Discussion}

We would like to take a closer look at how Generation $\mathrm{Z}$ differs from other generations. For this we tried to identify their features: 
- Their first experience with technology was in early childhood. From Sega and Tetris to iPhones and MacBooks, these people grew up hand in hand with technology.

- They suffer from severe attention deficit disorder. The new generation finds it difficult to concentrate even on what interests them. Therefore, they sit on their phones at a lecture, on the go and on a date, while watching TV.

- They want everything at once. Because of ambition, Generation $\mathrm{Z}$ does not want to stay in a company with vague growth prospects. They need the ability to climb the corporate ladder very quickly.

- The digital generation is fluent in multitasking. Young people no longer need to focus on one thing. They can text, work on a spreadsheet, and listen to music at the same time, without prejudice to any of these tasks.

- They need feedback on their actions. Generation $\mathrm{Z}$ is used to the fact that on the Internet, a review instantly appears on any of your actions, be it a like, repost, or comment. In real life, where this is not the case, lack of regular approval makes them frustrated and lost.

- Generation $\mathrm{Z}$ hates clear boundaries. In everything they do, they need a certain amount of flexibility. Wherever they can, they want to get this freedom.

- They need to clearly know what people want from them. Young people like getting clearly expressed tasks, requirements and required results.

From the above, we conclude that Generation $\mathrm{Z}$ has been determined to be digital consumers boldly shopping online. They stay online most of their time (working online, studying online, social media from 3 to 6 hours a day, watching movies and entertainment content online, etc.).

Based on this information, brands will strive in every possible way to use the opportunities for cooperation between business and customers. In any case, the interaction will become increasingly close and will be expressed in the form of UGC, feedback, recommendations, and advertising. It is common for Generation $\mathrm{Z}$ to be socially responsible in choosing brands, which provide benefit to society and set a positive agenda. Hence the love of creativity and creation, which is the basis for the advantage of brands that offer ideas for co-creating products and their individualization by the consumer himself. Social networks are becoming the main channel for delivering advertising information to a young audience with a focus on visual content (video, infographics) and the shortest formats possible: Generation $\mathrm{Z}$ consumes information fragmentarily, as they use several devices simultaneously.

Generation $\mathrm{Z}$ spends a lot of time on social media for communication, tracking trends, shopping, entertainment; they do all this in parallel, while at school or work, on vacation, etc. In our opinion, they are somewhat dependent on and are subject to the strong influence of the social networks. To better navigate the endless stream of network noise, they will turn to brands and people they trust to recommend products. The existing "Oprah effect" or "Tim Ferriss effect", and their strength is really difficult to overestimate today. As soon as they start talking about a product, everyone immediately pays attention to it and wants to try it. Companies will also likely create their own recommendations in a bid to create their own "effect".

As prices for product placement and podcast advertising have soared to heaven, the market is responding positively to this.

The media should inspire hope and faith in a brighter future. Best suited for this are Medium, YouTube, Instagram, Facebook, and other platforms where "little moments of life" can be presented as images or short videos.

In the short term, the most popular media will be those that can inspire the audience to believe, hope, gratitude, and strive for excellence.

Generation $\mathrm{Z}$ is more primed to collaboration and remote work than other generations. In addition, they are much more active in using modern technology for communication and work.

\section{Acknowledgements}

The work is performed according to the Russian Government Program of Competitive Growth of Kazan Federal University.

\section{References}

Ahmad, A. H., Idris, I., Mason, C., \& Chow, S. K. (2019). The impact of young celebrity endorsements in social media advertisements and brand image towards the purchase intention of young consumers. International Journal of Financial Research, 10(5), 54-65. https://doi.org/10.5430/ijfr.v10n5p54

Alzeaideen, K. (2019). The Effect of Total Quality Management on University Performance in Jordan. International Journal of Financial Research, 10(6), 10-25. https://doi.org/10.5430/ijfr.v10n6p283 
Ashman, R., Patterson, A., \& Brown, S. (2018). 'Don't forget to like, share and subscribe': Digital autopreneurs in a neoliberal world. Journal of Business Research, 92, 474-483. https://doi.org/10.1016/j.jbusres.2018.07.055

Baccarella, C. V., Wagner, T. F., Kietzmann, J. H., \& McCarthy, I. P. (2018). Social media? It's serious! Understanding the dark side of social media. European Management Journal, 36(4), 431-438. https://doi.org/10.1016/j.emj.2018.07.002

Bayindir, N., \& Kavanagh, D. (2018). GlobalWebIndex's flagship report on the latest trends in social media. Flagship Report, $2018 . \quad$ Retrieved from https://www.globalwebindex.com/hubfs/Downloads/Social-H2-2018-report.pdf

Curtis, B. L., Ashford, R. D., Magnuson, K. I., \& Ryan-Pettes, S. R. (2019). Comparison of smartphone ownership, social media use, and willingness to use digital interventions between generation $\mathrm{z}$ and millennials in the treatment of substance use: Cross-sectional questionnaire study. Journal of Medical Internet Research, 21(4), e13050-e13059. https://doi.org/10.2196/13050

Dimock, M. (2019). Defining generations: Where Millennials end and Generation Z begins. Pew Research Center, 17, $1-7$.

Djafarova, E., \& Rushworth, C. (2017). Exploring the credibility of online celebrities' Instagram profiles in influencing the purchase decisions of young female users. Computers in Human Behavior, 68, 1-7. https://doi.org/10.1016/j.chb.2016.11.009

Francis, T., \& Hoefel, F. (2018). True Gen': Generation $Z$ and its implications for companies. New York/ United States: Mckinsey \& Company.

Haefliger, S., Jäger, P., \& Von Krogh, G. (2010). Under the radar: Industry entry by user entrepreneurs. Research policy, 39(9), 1198-1213. https://doi.org/10.1016/j.respol.2010.07.001

Hernandez-de-Menendez, M., Díaz, C. A. E., \& Morales-Menendez, R. (2020). Educational experiences with Generation Z. International Journal on Interactive Design and Manufacturing (IJIDeM), 14(3), 847-859. https://doi.org/10.1007/s12008-020-00674-9

Jin, S. A. A., \& Phua, J. (2014). Following celebrities' tweets about brands: The impact of twitter-based electronic word-of-mouth on consumers' source credibility perception, buying intention, and social identification with celebrities. Journal of Advertising, 43(2), 181-195. https://doi.org/10.1080/00913367.2013.827606

Kaplan, A. M., \& Haenlein, M. (2010). Users of the world, unite! The challenges and opportunities of Social Media. Business Horizons, 53(1), 59-68. https://doi.org/10.1016/j.bushor.2009.09.003Get

Liu, C. Y., Qu, Z. Z., \& Zhao, H. S. (2017). The exploration of digital celebrities' development in commerce. China Market, 1, 62-63. Retrieved from https://www.diva-portal.org/smash/get/diva2:1331697/FULLTEXT01.pdf

Persada, S. F., Miraja, B. A., \& Nadlifatin, R. (2019). Understanding the generation Z behavior on D-learning: A Unified Theory of Acceptance and Use of Technology (UTAUT) approach. International Journal of Emerging Technologies in Learning (iJET), 14(5), 20-33.

Seemiller, C., \& Grace, M. (2018). Generation Z: A century in the making. Abingdon/ United Kingdom: Routledge.

Smith, T., \& Cawthon, T. W. (2017). Generation Z goes to college. College Student Affairs Journal, 35(1), 101-102.

Turner, A. (2015). Generation Z: Technology and social interest. The Journal of Individual Psychology, 71(2), 103-113. https://doi.org/10.1353/jip.2015.0021

White, J. E. (2017). Meet Generation Z: Understanding and reaching the new post-Christian world. Baker Books.

Yeh, C. H., Wang, Y. S., Hsu, J. W., \& Lin, S. J. (2020). Predicting individuals' digital autopreneurship: Does educational intervention matter?. Journal of Business Research, 106, 35-45. https://doi.org/10.1016/j.jbusres.2019.08.020

\section{Copyrights}

Copyright for this article is retained by the author(s), with first publication rights granted to the journal.

This is an open-access article distributed under the terms and conditions of the Creative Commons Attribution license (http://creativecommons.org/licenses/by/4.0/). 